\title{
The Use of Simulation Methods in the Analysis of the Manufacturing Process of Hex Allen Bolts
}

\author{
Irena NOWOTYŃSKA, Stanisław KUT, Mirosław OSETEK
}

\begin{abstract}
Forming tools play a very important role in the production of shaped bolts with the use of plastic forming method. In industrial practice, the technological process of conventional shaping is the cold forming plastic, which causes a considerable wear of shaping tools. Properly designed, constructed and operated tool enables to provide high quality products at a sufficiently high volume of production, low cost, and the required level of security. Consequently, this will allow the company to compete effectively in today's market. The paper shows the numerical analysis of stress prevailing in the die during the implementation of forging of hex internal Allen bolts depending on the size of the applied interference. The research has allowed determining the impact of interference, among others, on the distribution of hoop stress in the die during the manufacturing process of the bolts.
\end{abstract}

Keywords: Allen bolts; cold forming; load die; numerical simulation

\section{INTRODUCTION}

Bolted joints are widely used in all industry branches including the devices such as turbines, compressors designed for automotive industry, compressors designed for the aerospace industry, steam turbines, gas turbines, etc. The use of such connections makes it possible to dismantle and reassemble parts without replacing the connectors, which are sets of bolt joints. Bolts, as the elements connecting components and assemblies machines, are subjected to high demands as a huge percentage of these elements work in different environments, e.g. high aggressiveness. The advantage of Allen head bolts is a possibility to use them in places where the diameter of the head is only slightly greater than the diameter of the thread pin (Fig. 1) [1]. Moreover, the bolting or unbolting of such bolts do not require additional space on a plane perpendicular to the axis of the bolt, which allows the use of this type of bolts with limited side. The heads of the bolts made of the same materials and the same strength may be smaller in diameter in the case of using Allen key than in the case of spanners. In turn, the advantage of the Allen bolt is not slipping out the key (bolt driver) from the bolt in low pressure in the direction of the bolt axis.

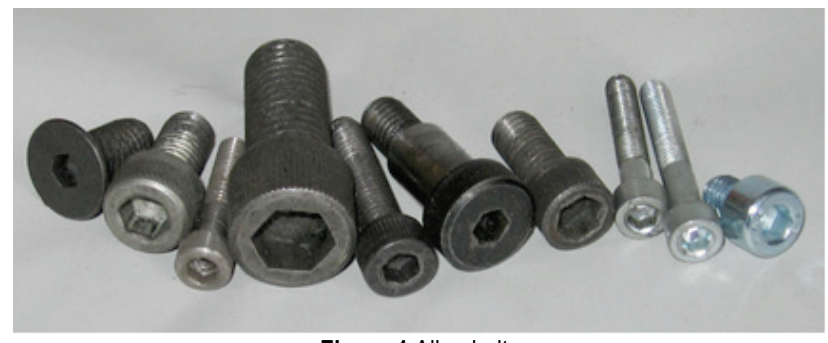

Figure 1 Allen bolts

In turn, the main measure of the quality of the tool is its reliability or the ability for long-term operation without defects. Reliability of the tool is closely related to its life. The definition of the tool life in this case is very flexible due to the large number of the determining factors. In industrial practice, the adverse phenomenon that may occur during the forging of bolts is e.g. tools cracking or other tools elements, their intense wear or permanent deformation. Thus, the tool life will be determined in each case by three destructive phenomena - cracking, wear and permanent deformation. Each of these effects will be present with a different intensity for various initial state of the tool. The forming tools play a very important role in the production of shaped bolts. In industrial practice, the technological process of conventional shaping is the cold forming plastic, which causes a considerable wear of shaping tools. Properly designed, constructed and operated tool enables to provide high quality products at a sufficiently high volume of production, low cost, and the required level of security. Consequently, this will ensure the company to compete effectively in today's market. Tool life and its usefulness for production depend on a number of factors, which often cause opposite effects. There are no clear criteria for the selection of materials and one needs to largely base on the experiences of producers and users of tools, including the possibilities offered by modern information technology tools in the form of computational programs supporting engineering in the analysis of processes and the design of tooling. Thanks to that it is possible to use simulations of data processes without having to conduct long-term experimental studies $[2 \div 12]$. Already, at research stage, the simulations can take into account certain factors and phenomena that have an unfavourable impact on the tool, and then design the process and instrumentation to eliminate them or at least limit to a certain extent.

The finite element method (FEM) is now a widely used engineering calculation tool. In most large and mediumsized enterprises the production cannot start before the specified properties of a product are positively verified using FEM. The main FEM assumption is a division of the continuous geometrical model into finite elements, connecting in so-called nodes, which results in the creation of a discrete geometric model. During the calculation with the use of the FEM any other physical quantities represented in the system by means of continuous functions (e.g. the load restraint, displacements, stresses) also undergo discretization. During discretization of specific physical size one tends to the maximum approximation of its discrete and continuous form using the approximation method. Therefore, when designing bolted connections, one should build a preliminary numerical model, which 
reflects the real object. Moreover, such a model will allow shortening the design process. Several studies include information confirming the possibility of modeling by MES of the selected technological operations occurring in the production of fasteners. For example, the works [13, 14] relate to simulation of various steps in the production of selected kinds of bolts using the Q form 3D software. There were described the simulation results of operations of upsetting the head and the diameter of the mandrel forming the rolling thread. The deformations distribution with the characteristic silent zones was obtained. In turn, in the work [13] an attempt was done to simulate the technological operation of manufacturing of hexagonalhead bolt in the technology of the head manufacturing by upsetting hexagonal in the die using non-waste technology. During upsetting the hexagon some unfilled sections occurred and the flash which disqualifies the product as incompatible with the relevant standards

Due to the strongly developing large-scale modelling methods and mathematical models of describing the structure of $[15 \div 22]$ in the literature one can find a combination of finite element method with cellular automata method [23, 24] applied to analyse the production process of fasteners. Simulation by CAFE method enables simultaneous calculation of the phenomena occurring in the macro and micro scale. In [25] CAFÉ was used in the simulation of technological process of the head upset in the manufacturing of fasteners during production of a hexagonal bolt. It was shown that the large-scale simulation method gives great opportunities to predict the development of micro-cracks as well as the accurate determination of actual local deformations.

The subject of the study were also the issues of bolt movement while trimming [26:29] and an analysis of nearly full technological process of forging fasteners incorporating the technology of production of hexagonal bolts for additional drawing operation [30, 31]. Research concerning the bolts was also presented in the works $[32 \div 35]$. In paper [32] the shrink fitting ratio was introduced by dividing the interference by the inner radius of the stress ring. In paper [33] was described the experience with cold forming of bolts, made of microalloyed steel, specially designed to enable elimination of thermal treatment. The paper [34] presents a new approach for the prediction of ductile fracture occurrence in multistage cold forging process chains. In turn in paper [35] experimental tests have been completed for high-strength 8.8 bolts for studying their mechanical performance subjected to tensile loading.

An analysis of abrasive wear of forming tools and an analysis of the impact of charge parameters selection to the process of manufacturing of hex bolts on their way of wear was carried out in $[36,37,38]$. One analysed the impact of a change in the diameter of wire rod in the drawing process on the dies wear, and then how this choice affects the wear of dies forming the coupling element in the cold forging.

The aim of the article is to show the use of numerical modelling for an analysis of the process of forming hex internal (Allen) bolts. Numerical simulations aimed primarily to analyse the distribution and stress values prevailing in the die during the forging operation, depending on the size of the applied interference.

\section{EXPERIMENTAL PROCEDURE}

The research subject was shaping operation of the Allen bolt head with the biggest die load. Prior to the numerical studies, an analysis was done of instrumentation and tools in the process realized experimentally in industrial conditions. Geometric model of instrumentation used in the numerical model was constructed based on the experimental model. The process for the bolt preparation takes place in several stages. The wire is fed into the machine where it is cut into appropriate lengths; then the desired shape is formed by the sequential steps of the recess, and the thread is rolled (Fig. 2).

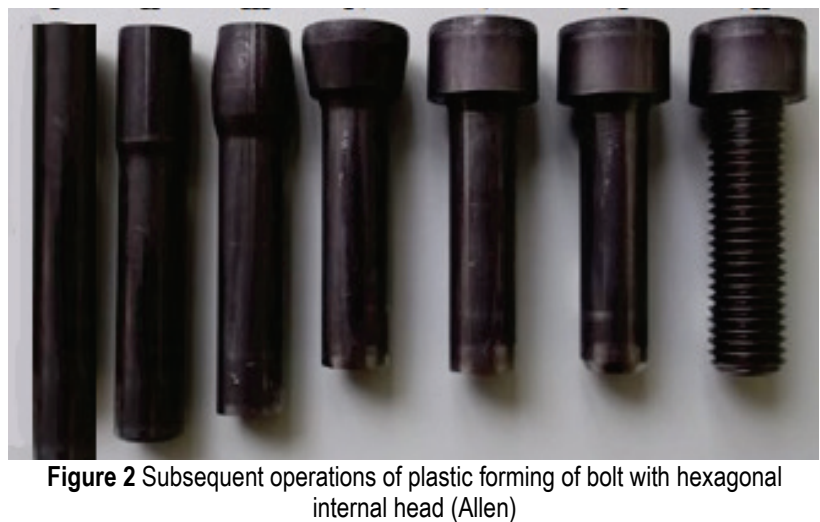

Most of the machines used to implement the process of bolts cold forging are horizontal presses, but there are also so-called vertical nailing machines. In all, the ultimate shape of the product depends on the upset and punch (one side) and the die (second). Punches are the kind of suitably shaped hammers, which deform the detail fixed in the die from the other side. The size of the forging (deformation) obtained during one stroke (at one station in the multi-die machine) is a function of the mechanical properties of the workpiece and the complexity of the workpiece [5].

In the present case, the process of bolts cold forging was implemented on the machine type SACMA SP38 EL. The bolts were made of steel type $30 \mathrm{MnB} 4$. The die of $\varnothing 12,51$ was applied. Mechanical properties of the bolt material (yield strength and the course of the strainhardening curve) were determined based on the static tensile test conducted on testing machine Zwick/Roell Z100.

As previously noted, in current technology a bolt is made during several steps (Fig. 2). Many years of industrial practice show that the lowest durability have the tools for the implementation of the fourth operation. It can be concluded that in this operation there is the biggest load of tools, which not only causes their most intense wear, but often leads to the formation of dangerous cracks in the tools. Therefore, this study was conducted for the fourth operation. As it is known, the tools for making bolts comprise a number of components that have to withstand high mechanical and thermal loads, and therefore have high durability. An experiment allowed isolating the most vulnerable places for loss of consistency or the use of tools, which translates into durability as one of the causes of these phenomena, can be badly chosen mounting interference. In industrial practice, the values of interference have been estimated. Therefore, the appearing negative phenomena 
prompted to perform numerical modelling to give an answer to the question what contributes to the occurrence of the aforementioned negative phenomena, and to take an attempt to eliminate them.

\section{NUMERICAL MODELLING}

Numerical calculations were performed using commercial software MARC/Mentat MSC Software. The process of forming the bolt was modelled in the fourth operation assuming several design variants of tools. The first involved the die without interference, three consecutive with an application of various mounting interference. This approach has allowed, among others, to determine the places of high stresses intensity between the die material and the material of the bolt. Furthermore, an analysis was done of the possibility of reducing unfavourable stresses in the die of the same size load, using interference mounting. For the test case, the relationship between the stress and the magnitude of interference in the considered range was shown. Material properties of the bolt were described taking the model of elastic-plastic body of nonlinear strain hardening. A two-dimensional geometric model of the process was built and then it was analysed on the assumption of axial symmetry (axisymmetric model). The geometric model consisting of seven deformable bodies that are in contact with each of "touching" type has been shown in Fig. 3.

The friction model was described by Coulomb's law. The coefficients of friction between the bolt and the die were 0,1 and between other tools 0,15 . For the construction of the finite element mesh of the deformed materials elements of class 4 type 10 - axisymmetric quadrilateral ring [39] were applied. Numerical simulation was performed using the global remeshing option.

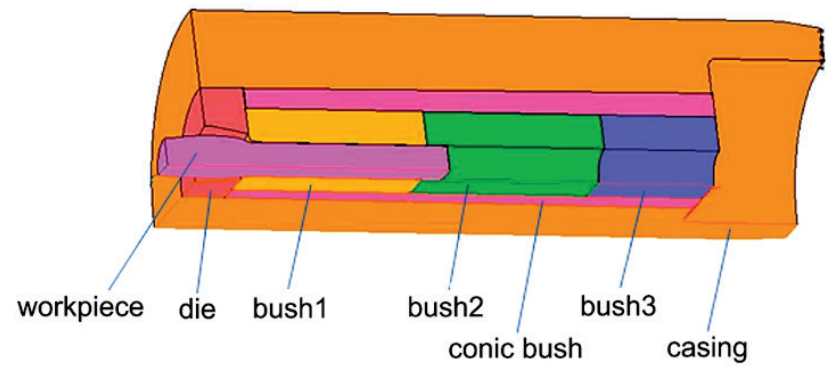

Figure 3 Geometric model of the analysed process

The size of the die elements and the bolt was approximately $0,20 \mathrm{~mm}$, while other materials approximated $0,4 \mathrm{~mm}$. In the research three different values of the mounting interference, i.e. $0,003 \mathrm{~mm} ; 0,006$ $\mathrm{mm} ; 0,009 \mathrm{~mm}$ were analysed, determining the hoop stresses occurring between the die and the housing during the forming of the bolt head. To determine the mounting interference $\delta$ the following formula was used:

$\delta=\frac{D_{z w}-D_{w p}}{2}$

Where: $D_{z w}$ - external die diameter, $\mathrm{mm} ; D_{w p}-$ internal diameter of tool hollow, $\mathrm{mm}$.

\section{$4 \quad$ RESULTS AND DISCUSSION}

The number and variety of factors affecting the tool life is difficult to define clearly. One of the main factors affecting the tool life is to follow technological parameters in the production, e.g. a suitable choice of mounting interference. Fig. 4-5 show the stress distribution in the bolt die and the degree of interference equal to $0,009 \mathrm{~mm}$ at the time of contact between the bolt and the die (Fig. 4) and during the final stage (Fig. 5).

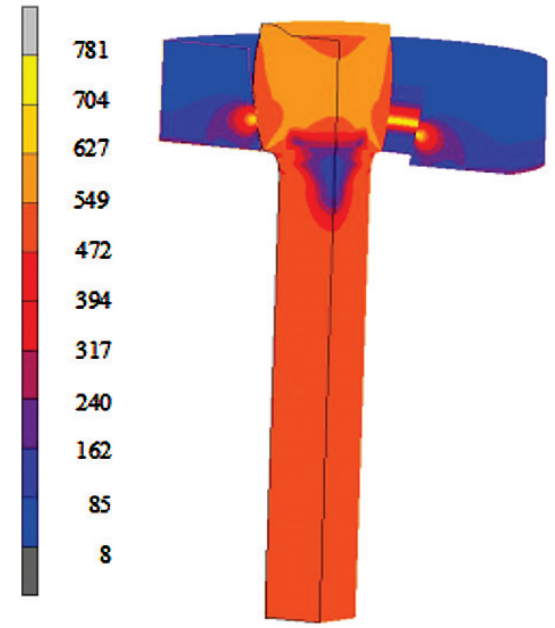

Figure 4 Intensity of stress distribution in $\mathrm{MPa}$ at the time of contact of the die with the bolt

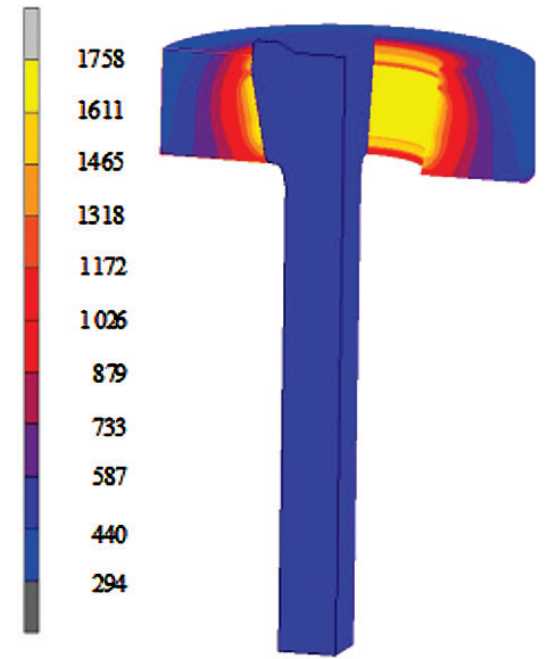

Figure 5 Intensity of stress distribution in $\mathrm{MPa}$ at the final stage of the process

Fig. 6 shows the stress distribution in the die during the production of bolts without using the interference and with an application of three different interferences between the die and the bolt. One needs to pay attention to the stresses that occur in individual cases due to the adoption of different scales for different variants.

In the case of the die where the interference has not been applied, the highest hoop stresses equal to $1240 \mathrm{MPa}$ were observed. The use of mounting interference 0,003 reduced the stress by about $2,5 \%$. The use of interference twice as much equal to $0,006 \mathrm{~mm}$ resulted in a slight decrease in the value of hoop stress in comparison with the interference of $0,003 \mathrm{~mm}$ at slightly above $3 \%$ reaching a value of $1200 \mathrm{MPa}$. The lowest values of the hoop stresses were recorded for the interference of $0,009 \mathrm{~mm}$, and 
compared with those that were achieved without the use of interference, they were reduced by more than $7 \%$, amounting to $1150 \mathrm{MPa}$.

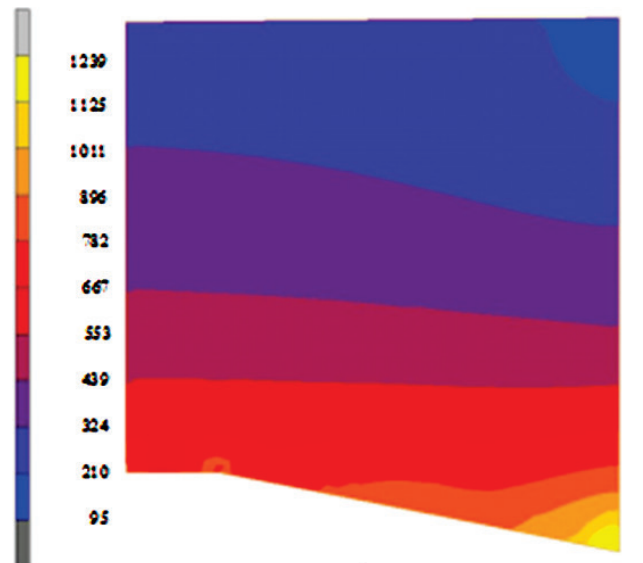

a)

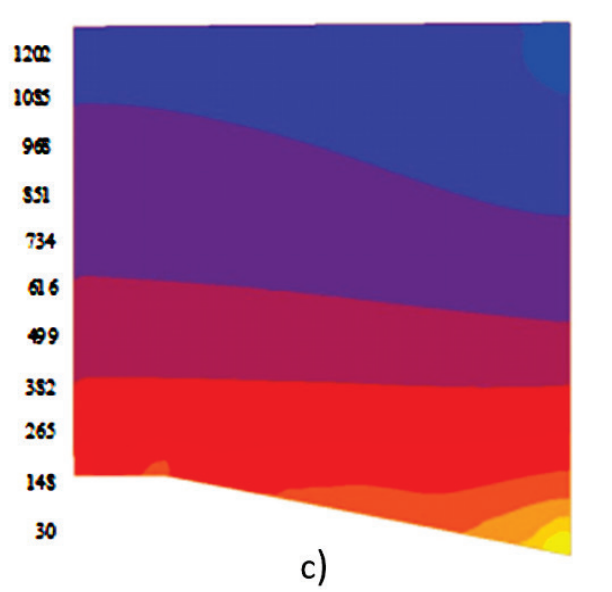

Figure 6 Distribution and values of hoop stresses in MPa in the die during the bolts manufacturing: a) without interference, b) with an interference of $0,003 \mathrm{~mm}, \mathrm{c}$ ) with an interference of $0,006 \mathrm{~mm}, \mathrm{~d}$ ) with an interference of $0,009 \mathrm{~mm}$

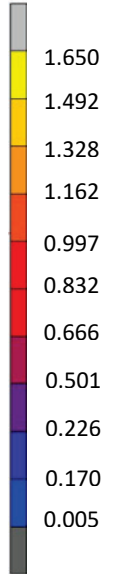

Figure 7 Distribution of equivalent plastic strain in the bolt head in the final phase of the process

\section{CONCLUSION}

The results presented in the article are an example of a computer-aided design technology and an analysis with special emphasis on the proper selection of process conditions required to obtain a high quality product (indications of places exposed e.g. to cracking, determination of the influence of interference on the distribution of hoop stresses), at a minimum cost (reduction
Fig. 7 shows the distribution of replacing plastic deformation in the bolt head in the final phase of the process.

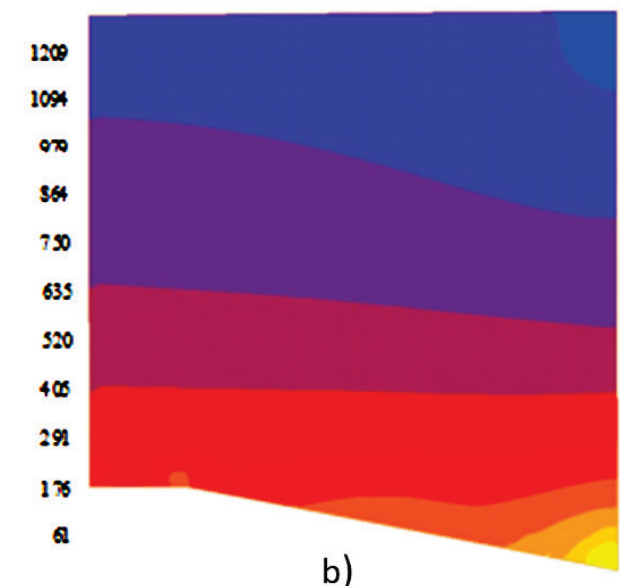

b)

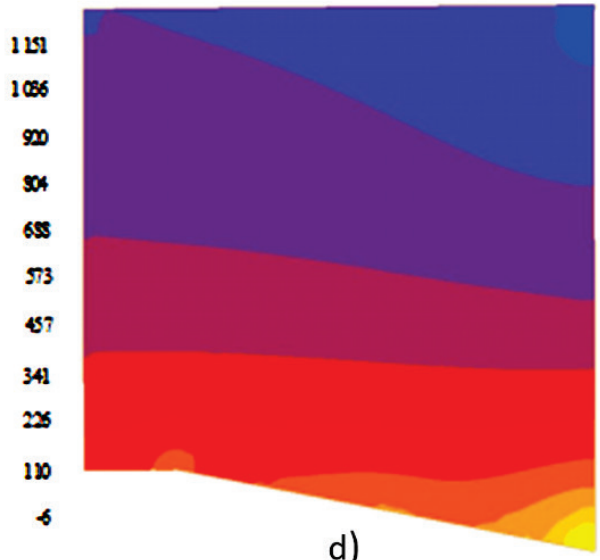

d)

of wastage). The example of the process of cold forging of the bolt with hexagonal head has been considered. The influence of different values of interference on the proper selection of process parameters and their influence on the final result as the shape of the product and tool life have been discussed.

It has been observed that the use of interference equal to $0,009 \mathrm{~mm}$ resulted in the greatest decrease in the value of hoop stresses in the die compared with other accepted values of interference, which may cause that the die material in the entire area will be more evenly loaded and, consequently, will reduce the level of stresses, which from the point of consumption and service life is very beneficial. However, one needs to keep in mind that the use of too large interference increases the risk of cracks appearing in the tools. In engineering practice, during the selection of the interference, it should be noted that during tools loading the stress gradients should be as low as possible. The results indicate the existence of the relationship between the applied values of the interference and the values of stresses in the dies with the application of the mounting interference.

\section{REFERENCES}

[1] http://www.srubki.com.pl/obrobka.html 
(Accessed on 08.09.2016)

[2] Yung-Chang, Y. et al. (2004). Estimation of tool wear in orthogonal cutting using the finite element analysis. Journal of Materials Processing Technology, 146, 82-91. https://doi.org/10.1016/S0924-0136(03)00847-1

[3] Żmudzki, A., Skubisz, P., Sińczak, J., \& Pietrzyk, M. (2006). Wykorzystanie metod symulacji w procesach kuźniczych. Obróbka Plastyczna Metali t. XVII, 3.

[4] Żmudzki, A., Węglarczyk, S., Kondek, T., \& Pietrzyk, M. (2005). Numerical simulation of advanced metal processing, Manufacturing systems development: industry expectations, ed. J. Jędrzejewski, Machine Engineering, 5(3-4), 12-23.

[5] Rudakov, W. L. (2004). Izgotovlenie boltov povyszennoi procnosti dlia rielsovych stikov ŜeleznogoroŜnogo puti. Kuznecno-Stampovovenoe Proizvodstvo: obrabotka materialov davleniem. Moskwa 3, 17-21.

[6] Öpöz, T., \& Chen, X. (2016). Chip Formation Mechanism Using Finite Element Simulation. Strojniški vestnik - Journal of Mechanical Engineering, 62(11), 636-646. https://doi.org/10.5545/sv-jme.2016.3523

[7] Pandilov, Z., Milecki, A., Nowak, A., Gorski, F., Grajewski, D., Ciglar, D., Mulc, T., \& Klaic, M. (2016). Virtual modelling and simulation of a CNC machine feed drive system. Transactions of FAMENA, 39(4), 37-54.

[8] Brncic, D. \& Gregov, G. (2017). Numerical simulation study of parallel hydraulic hybrid system for a delivery van. Tehnicki glasnik-Technical Journal, 11(1-2), 21-28.

[9] Ismail, M. I. S. \& Afieq, W. M. (2016). Thermal analysis on a weld joint of aluminium alloy in gas metal arc welding. Advances in Production Engineering \& Management, 11(1), 29-37. https://doi.org/10.14743/apem2016.1.207

[10] Yang B., Chen W., \& Lin C. (2017). The Algorithm and Simulation of Multi-Objective Sequence and Balancing Problem for Mixed Mode Assembly Line. International Journal of Simulation Modelling, 16(2), 357-367. https://doi.org/10.2507/IJSIMM16(2)C010

[11] Trzepiecinski T., Lemu H. G., \& Fejki el R. (2017). Numerical Simulation of Effect of Friction Directionality on Forming of Anisotropic Sheets. International Journal of Simulation Modelling, 16(4), 590-602. https://doi.org/10.2507/IJSIMM16(4)3.392

[12] Simunovic, G., Svalina, I., Simunovic, K., Saric, T., Havrlisan, S., \& Vukelic, D. (2016). Surface roughness assessing based on digital image features. Advances in Production Engineering \& Management, 11(2), 93-104. https://doi.org/10.14743/apem2016.2.212

[13] Kula, A. (2003). Analiza procesu wytwarzania elementów złącznych z elementami symulacji wybranych procesów. Master thesis. AGH Kraków.

[14] Trzepak, M. (2005). Optymalizacja procesu wytwarzania części złącznych na przykładzie śruby mocowania koła. Master thesis. AGH Kraków.

[15] Rauch, Ł., Madej, Ł., Gawąd, J., Kusiak, J., \& Pietrzyk M. (2007). Digital materials - nowe kierunki rozwoju symulacji numerycznej procesów przetwórstwa metali. Hutnik Wiadomości Hutnicze, 74, 208-216.

[16] http://anisotropy.mae.cornell.edu/downloads/dplab/> (Accessed on 08.09.2016)

[17] Biernacki, M., Chastel, Y., Digonnet, H., Resk, H., Coupez, T., \& Loge, R. E. (2007). Development of numerical tools for the multiscale modeling of rekrystalisation in metals, based on a digital material framework. Computer Methods in Material Science, 7, 142-149.

[18] Milenin, A., Muskalski, Z., \& Wiewiórowska, S. (2007). Modelowanie za pomocą MES rozwoju mikrostruktury w procesie ciągnienia drutów ze stali perlitycznej. Hutnik Wiadomości Hutnicze, 74, 70-75.

[19] Van Acker, K. \& Root, J. (1996). Neutrion diffraction measurement of the residual stress in the cementite and derrite phases of cold-drawn steel wires. Acta Materialia, 44, 4039-4049. https://doi.org/10.1016/S1359-6454(96)00051-1

[20] Milenin, A. (2006). Opracowanie metody uzyskiwania struktur ultra drobnoziarnistych podczas walcowania pakietowego blach. Sprawozdanie z projektu Nr 3 T08A007 27, Politechnika Częstochowska, 72.

[21] Milenin, A. (2004). FEM analysis of a multi-pass hydrodynamic drawing process of high carbon steel wires with different drawing direction. Journal of steel and Related Materials, 203-208.

[22] Rauch, Ł. \& Madej, Ł. (2010). Application of the automatic image processing in modeling of the deformation mechanisms based on the digital representation of microstructure. International Journal for Multiscale Computational Engineering, 8, 343-356. https://doi.org/10.1615/IntJMultCompEng.v8.i3.90

[23] Madej, Ł., Hodgson, P. D., \& Pietrzyk M. (2007). Multiscale rheological model of discontinuous phenomena in materials under deformation conditions. Computational Materials Science, 38, 685-691. https://doi.org/10.1016/j.commatsci.2006.04.007

[24] Madej, Ł., Hodgson, P. D., \& Pietrzyk, M. (2007). The validation of a multiscale rheological model of discontinuous phenomena during metal rolling. Computational Materials Science, 41, 236-241. https://doi.org/10.1016/j.commatsci.2007.04.002

[25] Madej, Ł. (2006). Development of the multi-scale analysis model to simulate strain localization occurring during material processing. PhD thesis. AGH Kraków.

[26] MacCormack, C. \& Monaghan, J. (2001). Failure analysis of cold forging dies using FEA. Journal of Materials Processing Technology, 117(1), 209-215. https://doi.org/10.1016/S0924-0136(01)01139-6

[27] MacCormack, C. \& Monaghan, J. (1998). An investigation into the reduction of tools stresses caused during a cold forming process by altering the corner fillet geometry. Irish Manufacturing Conference IMC 15, 55-64.

[28] MacCormack, C. \& Monaghan, J. (1999). A finite element analysis of cold forming dies using 2 and 3 dimensional models. Irish Manufacturing Conference IMC 16, 113-122.

[29] MacCormack, C., Monaghan, J., \& Ryall, J. (1999). Finite element analysis of hexagonal trimming dies. Fastener Technology International Magazine, December 1999/January 2000, 45-46.

[30] Ellinghauser, T. (2010). Advantages of simulations software for the fastener industry. Fastener Technology International Magazine, 26-28.

[31] Madej Ł., Węglarczyk S., \& Pietrzyk M. (2009). Simulation of drawing as important stage in the steel bolt manufacturing chain. Hutnik Wiadomości Hutnicze, 76, 71-73.

[32] Lee, H. C., Sarooshb, M. A., Songc, J. H., \& Ima, Y. T. (2009). The effect of shrink fitting ratios on tool life in bolt forming processes. Journal of materials processing technology, 209, 3766-3775. https://doi.org/10.1016/j.jmatprotec.2008.08.032

[33] Janicek, L., Petruska, J., Maros, B., \& Rusz, S. (2002). Cold forming of bolts without thermal treatment. Journal of Materials Processing Technology, 125-126, 341-346. https://doi.org/10.1016/S0924-0136(02)00296-0

[34] Bariani, P. F., Bruschi, S., Ghiotti, A., \& Simionato, M. (2011). Ductile fracture prediction in cold forging process chains. CIRP Annals - Manufacturing Technology, 60, 287290. https://doi.org/10.1016/j.cirp.2011.03.135

[35] Ying, H., Shen, L., Shidong, N., Yang, B., \& Sha, W. (2016). FE simulation and experimental tests of high-strength structural bolts under tension. Journal of Constructional Steel Research, 126, 174-186. https://doi.org/10.1016/j.jcsr.2016.07.021 
[36] Pietrzyk, M. (2009). Sprawozdanie z pracy badawczej, Niskowęglowe - wysokowytrzymałe stale bainityczne umacniane wydzieleniowo na wyroby kute na zimno. $\mathrm{Nr}$ R15, 032 03, (not published).

[37] Kuziak, R., Skóra, M., Węglarczyk, S., Paćko, M., \& Pietrzyk, M. (2011). Computer aided design of the manufacturing chain for fasteners. Computer Methods in Materials Science, 11, 243-250.

[38] Kuziak, R., Milenin, A., Paćko, M., Pietrzyk, M. (2011). Fasteners of bainitic steels manufactured by drawing and forging. Hutnik Wiadomości Hutnicze, 78, 74-77.

[39] MSC Software: MSC. Marc Volume B: Element Library, Version 2010

\section{Contact information:}

Irena NOWOTYŃSKA, Assistant Professor

Rzeszow University of Technology,

Faculty of Management

al. Powstańców Warszawy 8, 35-959 Rzeszów, Poland

E-mail: i_nowot@prz.edu.pl

Stanisław KUT, Associate Professor

Rzeszow University of Technology,

Faculty of Mechanical Engineering and Aeronautics

al. Powstańców Warszawy 8, 35-959 Rzeszów, Poland

E-mail: stan_kut@prz.edu.p

\section{Mirosław OSETEK,}

KOELNER Łańcucka Fabryka Śrub,

ul. Podzwierzyniec 41, 37-100 Łańcut, Poland

E-mail: miroslaw.osetek@koelner.pl 